\title{
Przetapianie laserowe stali mikrostopowej typu HSLA
}

\author{
Laser remelting of microalloyed HSLA-type steel
}

\section{Streszczenie}

W artykule przedstawiono badania dotyczące przetapiania wiązką laserową stali mikrostopowej typu HSLA - 28MnTiNbVB $\left(R_{m}=1060 \mathrm{MPa}\right)$ o grubości $12 \mathrm{~mm}$. Proces przetapiania został przeprowadzony przy zmiennej energii linowej przetapiania $w$ zakresie od 0,6 do $2,6 \mathrm{~kJ} / \mathrm{cm}$. Przeprowadzone badania wykazały, że uzyskane przetopienia charakteryzują się poprawnym kształtem, jednak w ich objętości występują pęcherze gazowe, które mogą pojawić się w związku z bardzo dużymi szybkościami chłodzenia, co powoduje utrudnione wydzielania się gazów ze strefy przetopienia. Pęcherze te powstają w wyniku uwięzienia gazów rozpuszczonych w metalu bądź w wyniku odparowania pierwiastków stopowych. Przetopienia mają strukturę martenzytu listwowego o twardości dochodzącej do 600 HV10. Listwy martenzytu są mniejsze, a drobniejsze wydzielenia węglików są gęściej ułożone niż w materiale rodzimym. Uzyskane wyniki badań wskazują, że stal 28MnTiNbVB wykazuje ograniczoną spawalność w warunkach badania.

Słowa kluczowe: stal typu HSLA; przetapianie laserowe; martenzyt; odpuszczanie
Abstract

In this article examinations of laser beam remelting of microalloyed HSLA steel grade - 28MnTiNbVB $\left(R_{m}=\right.$ $1600 \mathrm{MPa}), 12 \mathrm{~mm}$ thick were presented. Remelting process was carried with variable linear energy in range from 0.6 to $2.6 \mathrm{~kJ} / \mathrm{cm}$. Carried examinations have shown that remelted zones have correct geometry, but include gas pores that could be caused by very high cooling rates resulting in hindering gas evacuation from remelted zone. This gas pores are caused by trapping gases dissolved in metal or vaporizing alloying elements. Remelted zone is martensitic with lath structure a hardness of up to $600 \mathrm{HV} 10$. Laths are smaller additionally smaller precipitations are more tightly packed compared to parent material. Examination results show that steel 28MnTiNbVB exhibits limited weldability.

Keywords: HSLA-type steel; remelting welding; martensite; tempering

\section{Wstęp}

W wyniku szybkiego rozwoju techniki nastąpił wzrost wymagań, jakie stawiane są materiałom inżynierskim w zakresie wytrzymałości mechanicznych, oddziaływania korozyjno-erozyjnego, czy też odporności na wysoką temperaturę. Trwałość eksploatacyjna zależy od struktury, warstwy wierzchniej współpracujących ze sobą elementów we wszelkiego rodzaju maszynach, jak również elementów pozostających w kontakcie ze środowiskiem zewnętrznym. Własności te zależą nie tylko od możliwości przenoszenia obciążeń mechanicznych przez cały czynny przekrój elementu z zastosowanego materiału, lecz bardzo często także lub głównie od struktury i własności warstw wierzchnich. Ciągły rozwój materiałów, a także wykorzystanie technik inżynierii powierzchni pozwala spełnić te warunki przez kształtowanie mikrostruktury, składu fazowego i chemicznego, stanu naprężeń własnych w warstwach wierzchnich obrabianych elementów, a więc kształtowanie ich własności użytkowych. Niezwykle istotną zaletą technik inżynierii powierzchni jest to, że stwarzają szerokie możliwości wytwarzania produktów o żądanych własnościach na bazie istniejących już materiałów [1 $\div$ 7]. Obecnie obserwuje się tendencję do zastępowania tradycyjnych materiałów tańszymi, lecz o specjalnych własnościach warstwy wierzchniej, co stwarza duże możliwości rozwoju nowoczesnych metod przetwórstwa materiałów, a także doskonalenia obecnie stosowanych rozwiązań. W celu modyfikacji własności warstw wierzchnich materiałów szerokie zastosowanie mogą znaleźć metody spawalnicze, a w szczególności obróbka laserowa. Tego typu zastosowanie obróbki laserowej wynika w głównej mierze z własności promieniowania laserowego oraz jego oddziaływania na obrabiany materiał: nagrzewania, nadtapiania, odparowania, a w związku z tym możliwości wprowadzania różnych pierwiastków stopowych. Techniki laserowe dają możliwość wykonania wielu operacji technologicznych na różnych materiałach, od trudno obrabialnych mechanicznie, poprzez miękkie, na kruchych skończywszy, z wydajnością i dokładnością niejednokrotnie przewyższającą znacznie metody stosowane dotychczas. Dużą zaletą tego procesu jest również możliwość precyzyjnej regulacji parametrów procesu, takich jak: prędkość skanowania powierzchni przez wiązkę laserową oraz jej moc, średnica

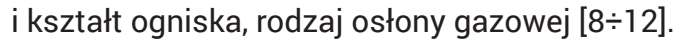

Dr hab. inż. Jacek Górka - Katedra Spawalnictwa, Politechnika Śląska w Gliwicach; dr hab. inż. Marek Opiela - Instytut Materiałów Inżynierskich i Biomedycznych; dr inż. Sebastian Stano - Instytut Spawalnictwa w Gliwicach.

Autor korespondencyjny/Corresponding author: jacek.gorka@polsl.pl 


\section{Badania własne}

Głównym celem pracy było zbadanie wpływu oddziaływania przetapiania wiązką laserową na własności i strukturę stali mikrostopowej typu HSLA - 28MnTiNbVB poddanej obróbce cieplno-plastycznej, a następnie odpuszczonej w temperaturze $550{ }^{\circ} \mathrm{C}[13]$.

\section{Materiał badawczy}

Badania przeprowadzono na stali konstrukcyjnej typu HSLA opracowanej w Politechnice Śląskiej, przeznaczonej do wytwarzania kutych elementów maszyn metodą obróbki cieplno-plastycznej o oznaczeniu 28MnTiNbVB [13]. Stale tego typu znajdują się w obszarze zainteresowania przemysłu samochodowego, które przy zastosowaniu właściwych technologii hutniczych pozwalają na wytwarzanie wyrobów o drobnoziarnistej strukturze, zapewniającej wysoką wytrzymałość i pożądaną podatność na kształtowanie technologiczne metodami tłoczenia, gięcia i innymi. Stale tej grupy zawierające mikrododatki $\mathrm{Nb}, \mathrm{Ti}, \mathrm{V}$ w ilości do ok. 0,1\%, a niekiedy także $\mathrm{N}$ i B wymagają starannie prowadzonego procesu wytapiania z zastosowaniem metalurgii wtórnej i odlewania w atmosferze ochronnej oraz przetwórstwa hutniczego w zakresie temperatury wydzielania się w austenicie odkształcanym plastycznie azotków, węglikoazotków i węglików wprowadzonych do stali mikrododatków. Dyspersyjne cząstki tych faz ograniczają rozrost ziarn austenitu zrekrystalizowanego w przerwach między kolejnymi etapami odkształcenia plastycznego stali na gorąco. Austenit drobnoziarnisty chłodzony z należytą szybkością z właściwie dobranej temperatury końca obróbki plastycznej ulega przemianie w drobnoziarniste produkty przemiany, zapewniające pożądane własności użytkowe wyrobów [6]. Badana stal posiada niską zawartość P, S oraz gazów, co świadczy o jej wysokiej czystości metalurgicznej (tablica I).

Odcinki płaskowników ze stali B zahartowane bezpośrednio z temperatury końca odkształcenia plastycznego, wynoszącej $900{ }^{\circ} \mathrm{C}$, poddane następnie odpuszczaniu w temperaturze $550^{\circ} \mathrm{C}$ wykazują strukturę martenzytu odpuszczonego z wydzieleniami ziarnistych i płytkowych cząstek $\mathrm{Fe}_{3} \mathrm{C}$, rozmieszczonych wewnątrz ziarn i na granicach listew ferrytu (rys. 1). Utworzone w tych warunkach wydzielenia płytkowe i ziarniste spełniają z osnową zależności przestrzenne ustalone przez Bagariackiego. W strukturze stali w tym stanie ujawniono także obecność wydzieleń złożonych węglików typu (Ti,Nb)C oraz dyspersyjnych wydzieleń węglikoazotków typu $(\mathrm{Ti}, \mathrm{Nb})(\mathrm{C}, \mathrm{N})$ (rys.2).
Stal 28MnTiNbVB charakteryzuje się wysokimi własnościami wytrzymałościowymi, przy zachowaniu dobrych własności plastycznych i energii łamania próbek Charpy V (tablica II). Uzyskane wartości twardości badanej stali w stanie ulepszonym cieplnie nie powinny stwarzać problemu w procesie obróbki skrawaniem.
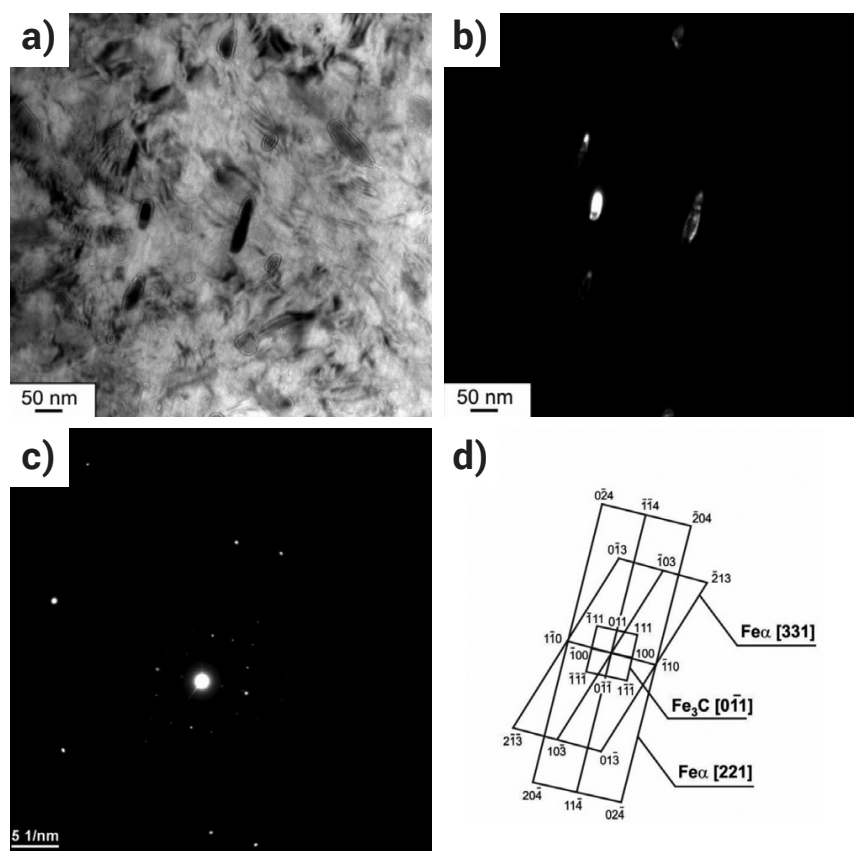

d)

Rys. 1. Dyspersyjne cząstki płytkowe $\mathrm{Fe}_{3} \mathrm{C}$ wewnątrz listew ferrytu stali $28 \mathrm{MnTiNbVB}$ (a), pole ciemne z refleksu (100) $\mathrm{Fe}_{3} \mathrm{C}$ (b), dyfrakcja (c); rozwiązanie dyfraktogramu z rys. 1c (d); obróbka cieplnoplastyczna: $900{ }^{\circ} \mathrm{C} /$ woda, temperatura odpuszczania: $550{ }^{\circ} \mathrm{C}[13]$

Fig. 1. Disperse plate precipitations of $\mathrm{Fe}_{3} \mathrm{C}$ inside ferrite laths of steel 28MnTiNbVB (a), dark field image from the (100) $\mathrm{Fe}_{3} \mathrm{C}(\mathrm{b})$, diffraction (c), solution of the diffraction from fig. 1c (d); thermomechanical treatment: $900{ }^{\circ} \mathrm{C} /$ water, tempering temperature: $550^{\circ} \mathrm{C}$ [13]

Wykres przemian fazowych austenitu przechłodzonego stali 28MnTiNbVB przedstawiono na rysunku 3. Badana stal wykazuje temperaturę $A_{c 3}=843^{\circ} \mathrm{C}, A_{c 1}=707^{\circ} \mathrm{C}$ oraz stosunkowo niską temperaturę Ms wynoszącą $370^{\circ} \mathrm{C}$. Badania dylatometryczne wykazały, że stal charakteryzuje się wysuniętą do krótkich czasów zatoką przemiany bainitycznej oraz ma odsunięte zatoki przemiany ferrytycznej i perlitycznej. Dzięki temu posiada strukturę martenzytyczno-bainityczną o przeważającym udziale martenzytu w szerokim zakresie szybkości chłodzenia.

Tablica I. Skład chemiczny badanej stali typu HSLA [13]

Table I. Chemical composition of the investigated HSLA-type steel [13]

\begin{tabular}{|c|c|c|c|c|c|c|c|}
\hline \multicolumn{8}{|c|}{ Stężenie pierwiastków, \% } \\
\hline C & Mn & Si & $\mathbf{P}$ & s & $\mathrm{Cr}$ & $\mathrm{Ni}$ & Mo \\
\hline 0,28 & 1,41 & 0,29 & 0,008 & 0,004 & 0,26 & 0,11 & 0,22 \\
\hline Nb & $\mathrm{Ti}$ & v & B & $\mathrm{Cu}$ & Al & $\mathbf{N}$ & 0 \\
\hline 0,027 & 0,028 & 0,019 & 0,003 & 0,20 & 0,025 & 0,0039 & 0,0006 \\
\hline
\end{tabular}

Tablica II. Własności mechaniczne i twardość badanej stali [13]

Table II. Mechanical properties and hardness of the investigated steel [13]

\begin{tabular}{|c|c|c|c|c|c|}
\hline \multicolumn{4}{|c|}{ Własności mechaniczne } & \multicolumn{2}{c|}{ Energia łamania próbek Charpy V } \\
\hline $\begin{array}{c}\mathbf{R}_{\mathrm{p} 0,2} \\
{[\mathrm{MPa}]}\end{array}$ & $\begin{array}{c}\mathbf{R}_{\mathrm{m}} \\
{[\mathrm{MPa}]}\end{array}$ & $\begin{array}{c}\mathbf{A} \\
{[\%]}\end{array}$ & $\begin{array}{c}\mathbf{Z} \\
{[\%]}\end{array}$ & $\begin{array}{c}\text { KV } \\
{[\mathrm{J}]}\end{array}$ & $\begin{array}{c}\text { KV } \\
\text { HRC }\end{array}$ \\
\hline 973 & 1057 & 13,5 & 51,5 & 69,3 & 55,0 \\
\hline
\end{tabular}




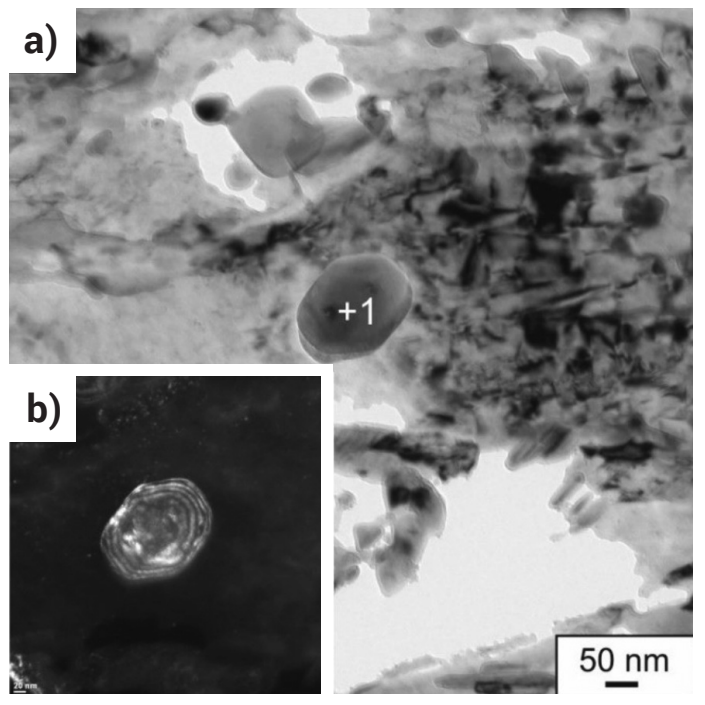

c)

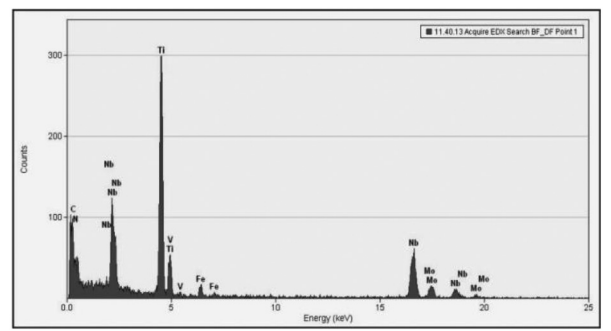

Rys. 2. Węglikoazotek $(\mathrm{Ti}, \mathrm{Nb})(\mathrm{C}, \mathrm{N})$ w ferrycie stali 28MnTiNbVB (a), pole ciemne (b), widmo EDS (c); obróbka cieplno-plastyczna: $900{ }^{\circ} \mathrm{C} /$ woda, temperatura odpuszczania: $550^{\circ} \mathrm{C}$

Fig. 2. Carbonitride $(\mathrm{Ti}, \mathrm{Nb})(\mathrm{C}, \mathrm{N})$ in ferrite of steel 28MnTiNbVB (a), dark field image (b), EDS spectrum (c); thermomechanical treatment: $900^{\circ} \mathrm{C} /$ water, tempering temperature: $550{ }^{\circ} \mathrm{C}$

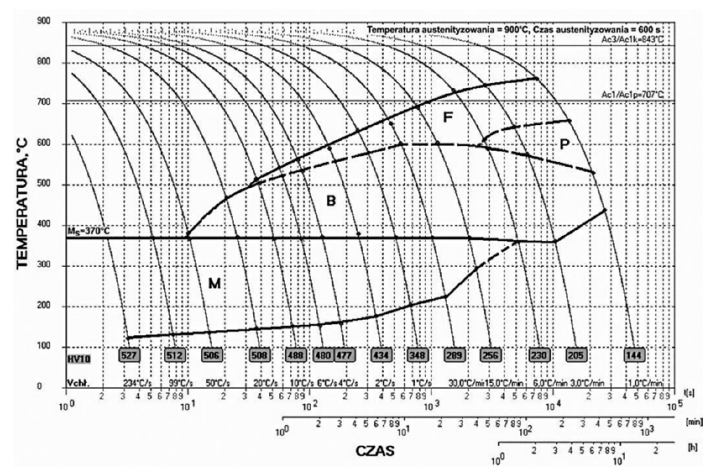

Rys. 3. Wykres CTPc przemian austenitu przechłodzonego stali 28MnTiNbVB [13]

Fig. 3. CCT diagram of supercooled austenite transformations of the steel 28MnTiNbVB [13]

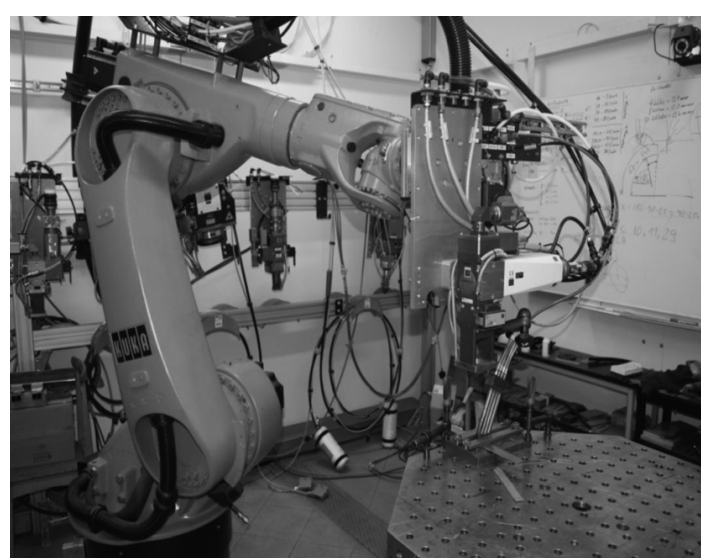

Rys. 4. Stanowisko do zrobotyzowanego przetapiania laserowego

Fig. 4. The position of robotic laser remelting

\section{Proces przetapiania}

Proces przetapiania przeprowadzono na stanowisku wyposażonym w robota przemysłowego KUKA KR 20/2HA, na którego kiści zamocowano system laserowy TruLaser Robot serii 5000 z głowicą D70 Hybrid, rysunek 3. Wykonano 9 przetopień przy zmiennych parametrach procesu, tablica III, rysunek 4.

Tablica III. Parametry przetapiania laserowego Table III. The parameters of the laser remelting

\begin{tabular}{|c|c|c|c|c|c|c|c|c|c|}
\hline $\begin{array}{c}\text { Numer } \\
\text { przetopienia }\end{array}$ & 1 & 2 & 3 & 4 & 5 & 6 & 7 & 8 & 9 \\
\hline $\begin{array}{c}\text { Moc } \\
{[\mathrm{kW}]}\end{array}$ & 3,5 & 3,5 & 3,5 & 5 & 5 & 5 & 6,5 & 6,5 & 6,5 \\
\hline $\begin{array}{c}\text { Prędkość } \\
\text { przetapiania } \\
\text { [m/min] }\end{array}$ & 1,5 & 2,5 & 3,5 & 1,5 & 2,5 & 3,5 & 1,5 & 2,5 & 3,5 \\
\hline $\begin{array}{c}\text { Energia liniowa } \\
\text { przetapiania } \\
{[\mathrm{kJ/cm}]}\end{array}$ & 1,40 & 0,84 & 0,60 & 2,00 & 1,20 & 0,86 & 2,60 & 1,56 & 1,11 \\
\hline
\end{tabular}

Uwagi:

Gaz osłonowy: Ar (ISO 14175: I1) - 18 I/min, dysza poczwórna (flet), głowica D70 Hybrid;

$F_{c}=200 \mathrm{~mm}, F_{o g}=400 \mathrm{~mm}$, średnica światłowodu: 0,3 mm, średnica ogniska: $0,6 \mathrm{~mm}, \mathrm{ZR}=7,5 \mathrm{~mm}$

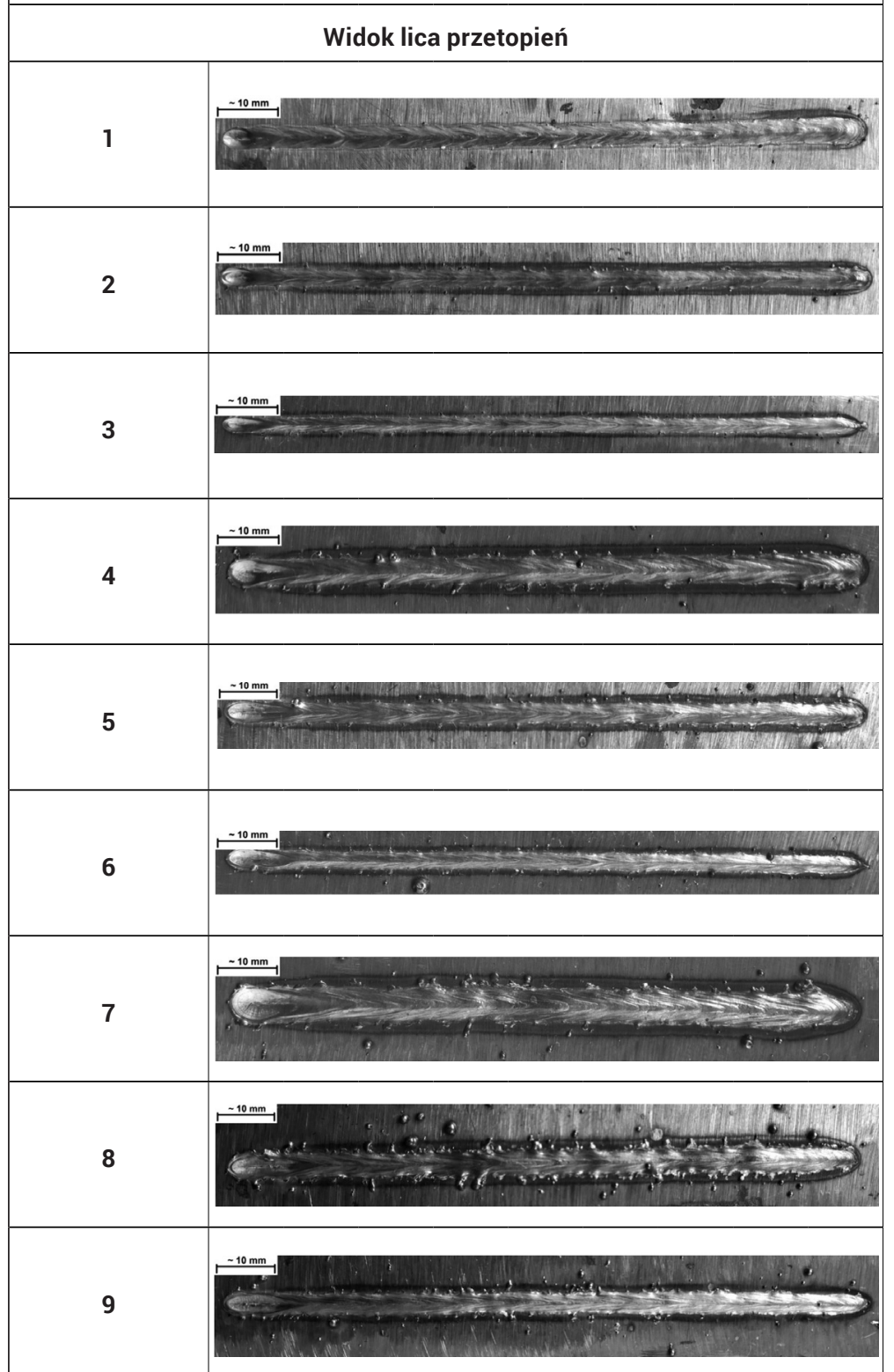

Rys. 5. Widok lica przetopień

Fig. 5. View faces remelted 


\section{Badania przetopień}

Uzyskane przetopienia po przeprowadzeniu badań wizualnych na podstawie wymagań normy poddano badaniom niszczącym w takim zakresie jak:

- badania metalograficzne makroskopowe na mikroskopie świetlnym stereoskopowym Olympus SZX9; próbki do badań trawiono odczynnikiem Adlera;

- badania metalograficzne mikroskopowe na mikroskopie świetlnym NIKON ECLIPSE MA100; próbki do badań trawiono w nitalu;

- pomiar twardości za pomocą urządzenia Vickers 401MVD firmy Wilson Wolpert, przy obciążeniu $1 \mathrm{~kg}$, według schematu na rysunku 5;

- określeniu pola powierzchni strefy przetopienia.

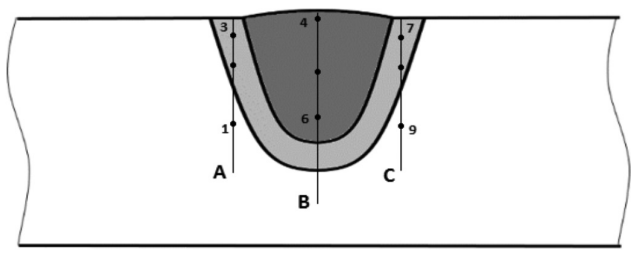

Rys. 6. Schemat rozmieszczenia punktów pomiaru twardości przetopień stali 28MnTiNbVB

Fig. 6. Scheme of arrangement points hardness measurement steel 28MnTiNbVB

\section{Analiza wyników badań}

Przeprowadzone badania makroskopowe wykazały, że przetopienia wykonane wiązką laserową charakteryzują się wąskim licem w zakresie 2,4-3,6 mm oraz stosunkowo głębokim wtopieniem w zakresie 3,6-6,2 mm. W każdym przypadku badania metalograficzne makroskopowe ujawniły obecność pęcherzy gazowych, które mogą pojawić się w związku

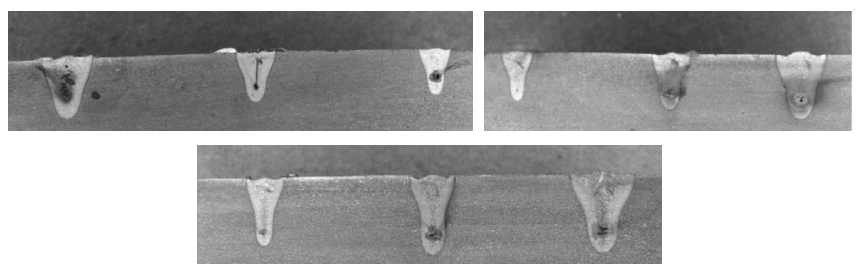

Rys. 7. Makrostruktura przetopień stali $28 \mathrm{MnTiNbVB}$, trawienie - Adler, przetopienia w kolejności od 1 do 9

Fig. 7. The microstructure of the $28 \mathrm{MnTiNbVB}$ steel remelting, etchant - Adler, remelting in order from 1 to 9 z bardzo dużymi szybkościami chłodzenia, co powoduje utrudnione wydzielania się gazów ze strefy przetopienia. Pęcherze te powstają w wyniku uwięzienia gazów rozpuszczonych w metalu bądź w wyniku odparowania pierwiastków stopowych. Pomiary cech geometrycznych przetopień wykonano w programie Autodesk Design Review 2013, rysunek 6, tablica IV.

Zgodnie z pozycją literaturową [13] materiał podstawowy (stal 28MnTiNbVB) powinien wykazywać strukturę martenzytu odpuszczonego z dyspersyjnymi wydzieleniami węglików. Mikrostruktura materiału podstawowego jest dobrze widoczna na fotografiach linii wtopienia przetopień wykonanych laserem. Charakterystyczną cechą linii wtopienia, w przypadku każdego z przetopień, jest występowanie w jej obszarze cementytu $\mathrm{Fe}_{3} \mathrm{C}$ w postaci ziarnistej. Przetopienia wykonane laserem, ze względu na niewielką energię liniową przetapiania nieprzekraczającą $3 \mathrm{~kJ} / \mathrm{cm}$ charakteryzują się niewielką szerokością strefy występowania cementytu, która jest zbliżona w każdym z dziewięciu przypadków, rysunek 7 . Na podstawie wykresu CTPc oraz wyników badań metalograficznych można ustalić mikrostrukturę badanych przetopień. Próbki po przetapianiu były chłodzone w powietrzu, co zapewnito odpowiednio wysoką szybkość chłodzenia potrzebną do uzyskania struktury martenzytu (rys. 8). Przetopienia mają strukturę martenzytu listwowego, na co wskazuje również zmierzona wysoka twardość. Listwy martenzytu są jednak w tym przypadku zdecydowanie mniejsze, a drobniejsze wydzielenia węglików są gęściej ułożone niż w materiale rodzimym.

Przeprowadzone pomiary twardości wykazały znaczący wzrost twardości w strefie odziaływania ciepła. W każdym z analizowanych przypadków, niezależnie od parametrów przetapiania, doszło do wzrostu twardości w strefie przetopienia, jak i SWC. Twardość stref przetopionych wiązką laserową wzrosła od ok. 370 HV10 przez 420 do 530 HV10 w strefie wpływu ciepła, natomiast w obszarze przetopionym wartość twardości osiągnęła poziom 600 HV10, tablica V, rysunek 8.

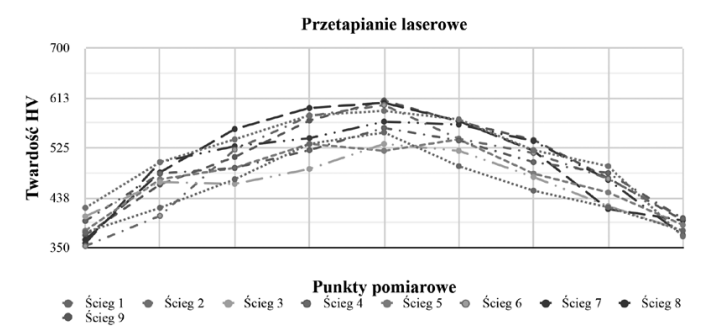

Rys. 9. Rozkład twardości w obszarze przetopienia stali 28MnTiNbVB Fig. 9. Distribution of hardness in the area of remelted steel 28MnTiNbVB

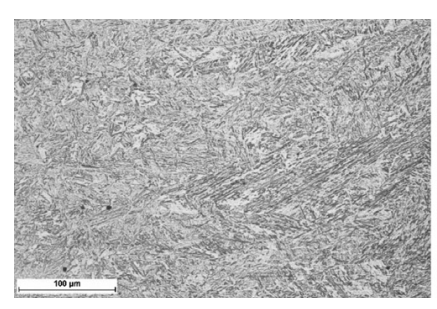

Przetopienie

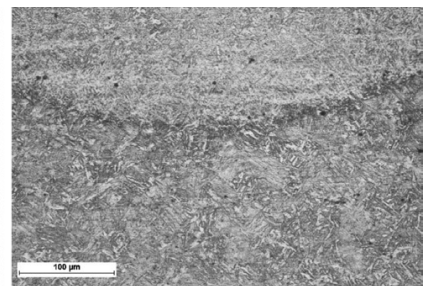

Linia przetopienia

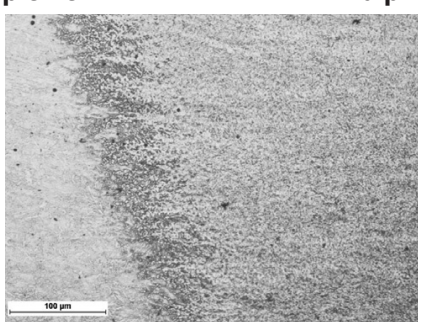

Strefa wpływu ciepła (SWC)

Rys. 8. Mikrostruktura obszaru przetopienia - przetopienie $\mathrm{nr} 7$

Fig. 8. Microstructure area remelting - remelting No. 7 
Tablica IV. Pomiar pola powierzchni strefy przetopienia stali 28MnTiNbVB

Table IV. The measurement of the surface area of the zone melted 28MnTiNbVB steel

\begin{tabular}{|c|c|c|c|c|}
\hline Numer przetopienia & $\begin{array}{l}\text { Przetopienie } \\
{\left[\mathrm{mm}^{2}\right]}\end{array}$ & $\begin{array}{l}\text { Przetopienie } \\
{\left[\mathrm{mm}^{2}\right]}\end{array}$ & $\begin{array}{l}\text { Głębokość wtopienia } \\
\text { [mm] }\end{array}$ & $\begin{array}{c}\text { Szerokość lica } \\
{[\mathrm{mm}]}\end{array}$ \\
\hline L1 & 5,5 & 10,5 & 4,7 & 3,6 \\
\hline L2 & 3,5 & 6,1 & 3,8 & 3,0 \\
\hline L3 & 2,7 & 4,6 & 3,6 & 2,4 \\
\hline L4 & 8,0 & 15,5 & 5,7 & 4,1 \\
\hline L5 & 6,0 & 9,7 & 4,8 & 3,2 \\
\hline L6 & 3,3 & 6,4 & 4,1 & 2,6 \\
\hline L7 & 10,0 & 18,6 & 6,2 & 4,8 \\
\hline L8 & 6,5 & 12,9 & 5,9 & 3,4 \\
\hline L9 & 4,7 & 8,9 & 5,2 & 2,6 \\
\hline
\end{tabular}

Tablica V. Wyniki pomiaru twardości HV10 w obszarach przetopień stali 28MnTiNbVB

Table V. The results of measuring the hardness HV10 in areas remelting steel 28MnTiNbVB

\begin{tabular}{|c|c|c|c|c|c|c|c|c|c|}
\hline \multicolumn{10}{|c|}{ Punkty pomiarowe wg. rysunku 5} \\
\hline $\begin{array}{c}\text { Linia } \\
\text { pomiarowa }\end{array}$ & $1 \mathrm{~A}$ & $2 A$ & $3 A$ & 4B & 5B & $6 B$ & 7C & $8 \mathrm{C}$ & $9 \mathrm{C}$ \\
\hline Nr ściegu & \multicolumn{9}{|c|}{ Przetapianie laserowe } \\
\hline 1 & 380 & 447 & 554 & 580 & 537 & 482 & 468 & 421 & 370 \\
\hline 2 & 393 & 405 & 440 & 537 & 580 & 543 & 471 & 417 & 381 \\
\hline 3 & 365 & 456 & 480 & 511 & 570 & 547 & 495 & 458 & 363 \\
\hline 4 & 350 & 443 & 503 & 533 & 578 & 559 & 501 & 474 & 373 \\
\hline 5 & 386 & 432 & 510 & 566 & 581 & 570 & 513 & 458 & 393 \\
\hline 6 & 353 & 406 & 522 & 581 & 600 & 541 & 516 & 471 & 402 \\
\hline 7 & 358 & 500 & 528 & 542 & 571 & 566 & 537 & 469 & 372 \\
\hline 8 & 364 & 482 & 558 & 595 & 604 & 572 & 520 & 418 & 398 \\
\hline 9 & 372 & 416 & 509 & 573 & 608 & 571 & 539 & 472 & 398 \\
\hline
\end{tabular}




\section{Podsumowanie}

Wyniki badań metalograficznych połączeń spawanych wiązką laserową oraz ocena wizualna ich jakości wykazały, że stal 28MnTiNbVB typu HSLA charakteryzuje się ograniczoną spawalnością w warunkach badania. Badania wykazały, że uzyskane przetopienia charakteryzuja się poprawnym kształtem, jednak w ich objętości występują pęcherze gazowe, które mogą pojawić się w związku z bardzo dużymi szybkościami chłodzenia. Twardość stali 28MnTiNbVB niezależnie od mocy wiązki laserowej zmienia się w zakresie 380 - 530 HV10 w strefie wpływu ciepła, aż do wartości maksymalnej ok. 590 - 605 HV10 w strefie największego odziaływania źródła ciepła. Strefa stopionego materiału podstawowego wykazuje strukturę martenzytu listwowego o twardości dochodzącej do 600 HV10. Listwy martenzytu są mniejsze, a drobniejsze wydzielenia węglików są gęściej ułożone niż w materiale rodzimym. Strefa wpływu ciepła charakteryzuje się strukturą martenzytyczno-bainityczną. Wzrost energii liniowej przetapiania oraz obniżona szybkość chłodzenia wpływa na zwiększenie udziału struktur bainitycznych w obszarach przetopionych. Ilość dostarczonego ciepła do materiału podstawowego wyraźnie wpływa na jego własności i strukturę, powodując umocnienie i pogorszenie własności plastycznych.

\section{Literatura}

[1] Grajcar A., Różański M.: Spawalność wysokowytrzymałych stali wielofazowych AHSS, Przegląd Spawalnictwa nr 3/2014, str. 22-27.

[2] Nishioka K., Ichikawa K.: Progress in termomechanical control of steel plates and their commercialization, Science and Technology of Advanced Materials, vol. 13, No. 2, April 2012, pp. 1-20.

[3] Krajewski S., Nowacki J.: Mikrostruktura i właściwości stali o wysokiej wytrzymałości AHSS, Przegląd Spawalnictwa nr 7/2011, str. 45-50.

[4] Stano S.: Spawanie laserowe blach o zróżnicowanej grubości przeznaczonych na półfabrykaty karoserii samochodowych typu tailored blanks, Biuletyn Instytutu Spawalnictwa nr 2/2005, str. 24-28.

[5] Dobrzański L.A., Jonda E., Klimpel A., Lisiecki A., Wpływ laserowego przetapiania i stopowania na strukturę i własności warstw wierzchnich stali X40CrMoV5-1, Przegląd Spawalnictwa, nr 3/2009, s. 3-8.

[6] Lee, H. Shin, K. Park: Evaluation of high strength TMCP steel weld for use in cold regions, Journal of Constructional Steel Research 74 (2012) pp. 134-139.

[7] Górka J.: Weldability of thermomechanically treated steels having a high yield point, Archives of Metallurgy and Materials, Volume 60, Issue 1/2015, pp. 469-475.

[8] Opiela M.: Elaboration of thermomechanical treatment conditions of Ti-V and Ti-Nb-V microalloyed forging steels, Archives of Metallurgy and Materials, 59 (2014) pp.1181-1188.

[9] Dudek A., Nitkiewicz Z., Prognosis of effects of remelting performed by means of plasma arc, Archives of Foundry Engineering, vol. 7, 2/2007, s. $79-82$.

[10] Patejuk A., Napadłek W., Przetakiewicz W., Wpływ stopowania laserowego i napawania metodą TIG na żaroodporność stali 50H21G9N4, Krzepnięcie Metali i Stopów, nr 27/1996, s. 207-215.

[11] Opiela M., Effect of thermomechanical processing on the microstructure and mechanical properties of $\mathrm{Nb}-\mathrm{Ti}-\mathrm{V}$ microalloyed steel, Journal of Materials Engineering and Performance, 23 (2014) pp. 3379-3388.

[12] Pilarczyk J., Banasik M., Stano S., Dworak J., Spajanie laserowe z materiałem dodatkowym i mechanicznym układem śledzenia złącza, Przegląd Spawalnictwa, nr 12/2011, s. 9-14.

[13] Opiela M.: Kształtowanie struktury i własności mechanicznych odkuwek ze stali mikrostopowych w procesie obróbki cieplno-plastycznej, Wydawnictwo Politechniki Śląskiej, Monografia nr 555, Gliwice, 2015. 